\title{
IGF1R, IGFALS, and IGFBP3 gene copy number variations in a group of non- syndromic Egyptian short children
}

\author{
Islam M. Fadel ${ }^{1 *}$ D, Moustafa H. Ragab², Ola M. Eid', Nivine A. Helmy ${ }^{1}$, Hala T. El-Bassyouni ${ }^{3}$ and Inas Mazen ${ }^{3}$
}

\begin{abstract}
Background: Insulin-like growth factor-1 (IGF-1) is required for normal intrauterine and postnatal growth, and this action is mediated through IGF1 receptor (IGF1R). IGF1R copy number variants (CNVs) can cause pre- and postnatal growth restriction, affecting an individual's height. In this study, we used multiplex ligation-dependent probe amplification (MLPA) to detect CNVs in IGFIR, IGFALS, and IGFBP3 genes in the diagnostic workup of short stature for 40 Egyptian children with short stature.

Results: We detected a heterozygous deletion of IGF1R (exons 4 through 21) in 1 out of the 40 studied children (2.5\%). Meanwhile, we did not detect any CNVs in either IGFALS or IGFBP3.

Conclusion: The diagnostic workup of short stature using MLPA for CNVS of IGF1R and other recognized heightrelated genes, such as SHOX and GH, in non-syndromic short stature children can be a fast and inexpensive diagnostic tool to recognize a subcategory of patients in which growth hormone treatment can be considered.
\end{abstract}

Keywords: Short stature, Copy number variations (CNVs), Multiplex ligation-dependent probe amplification (MLPA), IGF1R, ALS, IGFBP3

\section{Background}

Short stature is a condition in which the height of an individual is more than 2 standard deviation (SD) below the corresponding mean height for a given age and sex in a population [1]. Small for gestational age (SGA) is defined as a birth weight and/or birth length that is below - 2.0 SD scores (SDS) for the gestational age in a certain population [2]. In the majority of short children, no final diagnosis can be reached, and they are categorized under idiopathic short stature (ISS) or SGA with failure of catch-up growth [3].

Insulin-like growth factor-1 (IGF-I) is essential for normal intrauterine and postnatal growth. The growthpromoting functions of IGF-I are mediated via the IGF1 cell receptor (IGF1R) $[4,5]$.

\footnotetext{
* Correspondence: dr.islamfadel@gmail.com

${ }^{1}$ Department of Human Cytogenetics, National Research Centre, El Buhouth St., Dokki, Cairo 12622, Egypt

Full list of author information is available at the end of the article
}

IGF1R is a tetrameric $(\alpha 2 / \beta 2)$ transmembrane tyrosine kinase [6]. This receptor plays a pivotal role in the regulation of cell proliferation and metabolism and influences cancer development and life span [7-9].

The heterozygous mutations of the IGF1R gene lead to intrauterine and postnatal growth retardation and microcephaly. This mutation also causes a variable degree of psychomotor retardation and dysmorphic features $[4,10-12]$. Meanwhile, individuals having homozygous deletion or mutation of IGF-1 suffer from profound intrauterine and postnatal growth failure, microcephaly, intellectual disabilities, sensorineural deafness, and dysmorphic features [3, 13, 14].

IGF1R copy number variants (CNVs) may lead to preand postnatal growth restriction. Several pure $15 \mathrm{q} 26$ monosomies, including those with breakpoints proximal to the IGF1R gene, have been described in the literature $[11,15-17]$.

\section{Springer Open}

(c) The Author(s). 2021 Open Access This article is licensed under a Creative Commons Attribution 4.0 International License, which permits use, sharing, adaptation, distribution and reproduction in any medium or format, as long as you give appropriate credit to the original author(s) and the source, provide a link to the Creative Commons licence, and indicate if changes were made. The images or other third party material in this article are included in the article's Creative Commons licence, unless indicated otherwise in a credit line to the material. If material is not included in the article's Creative Commons licence and your intended use is not permitted by statutory regulation or exceeds the permitted use, you will need to obtain permission directly from the copyright holder. To view a copy of this licence, visit http://creativecommons.org/licenses/by/4.0/. 
Circulating IGF-1 is bound to IGF-binding proteins (IGFBPs), mainly to IGFBP-3 and the acid-labile subunit (ALS), forming a ternary complex. ALS has a major role in stabilizing this ternary complex and extending the IGF-1 half-life markedly $[18,19]$. Patients with ALS mutations have a markedly decreased IGF-1 and extremely low IGFBP-3 levels. These patients mostly show a moderately short stature, but the phenotype can be variable $[20,21]$.

Among the candidate genes for ISS are GH, GHR, STAT5B, and IGFALS; however, mutations in these genes are rare [22-25]. Meanwhile, the probable candidate genes for SGA include IGF1, IGF2, and IGF1R.

Growth hormone (GH) treatment can lead to a considerable height improvement in patients with IGF1R haploinsufficiency but not more than the expectation from the target mid-parental height $[11,26]$. The multiplex ligation-dependent probe amplification (MLPA) was proposed as an economical screening assay to detect intragenic IGF1R deletions in short children given that appropriate genetic diagnosis will lead to the recognition of patients suitable for $\mathrm{GH}$ treatment [3, 12, 27].

In this study, we utilized MLPA as a rapid and inexpensive tool to detect CNVs in the IGF1R gene in the diagnostic workup of short stature. In this report, we describe a patient with a deletion of exons 4-21 in one allele of IGF1R gene and who presented to our clinic with short stature.

\section{Methods}

This study was conducted at The National Research Centre - Egypt over a period of 3 years and was approved by its Medical Ethical Committee. Informed written consent was obtained from parents of the included cases. A total of 40 short children were included in the study. Disproportionate short stature, such as Leri-Weill dyschondrosteosis/Langer mesomelic dysplasia syndromes and skeletal dysplasia, was excluded clinically. Chromosomal abnormalities, e.g., Turner syndrome, were excluded by conventional karyotyping. SHOX CNVs were excluded using MLPA assay [28].

Complete medical history was obtained with the general emphasis on the family history to construct a pedigree for three consecutive generations. Consanguinity status, family history of similar condition, and parental heights were documented. Physical examination and the nutritional status were carried out to exclude malnutrition status, systemic diseases, and clinically suspected syndromic cases. Birth weight, GH profile, bone age, and height in SDS were documented.

\section{MLPA assay}

DNA extraction from $3 \mathrm{ml}$ peripheral blood lymphocytes from the 40 cases and reference samples (one reference for 7 patients sample with a minimum of three references per test) was carried out using the QIAamp DNA Mini Kit, in accordance with the manufacturer's instruction. The quality and quantity of the DNA samples were determined using a NanoDrop ${ }^{\circ}$ spectrophotometer.

IGF1R, IGFALS, and IGFBP3 CNV evaluation was carried out using $\mathrm{SALSA}^{\circ} \mathrm{MLPA}^{\circ} \mathrm{P} 217-\mathrm{B} 2$ IGF1R probemix $\mathrm{B} 2$, following the manufacturer's instruction (MRC-Holland) $[29,30]$. This probemix contained 42 MLPA probes for IGF1R, IGFALS, and IGFBP3, with the amplification products between 127 and 472 nt. This probemix contained one probe per exon for exons 3 to 20, two probes for exons 1 and 2, and three probes for exon 21 for the IGF1R gene. The probemix also contained one probe for each exon of the IGFBP3 (five exons) and IGFALS (two exons) genes. In addition, a second probe for IGFBP3 exon 5 and for IGFALS exon 2 has been added. Eight reference probes were included in this probemix, detecting eight different autosomal chromosomal locations.

DNA denaturation and overnight hybridization of the MLPA probemix were performed, followed by probe ligation and amplification on the next day. The separation of amplified products was conducted using a Genetic Analyzer ABI 3500 (USA). The interpretation of the results was performed using the Coffalyser.Net ${ }^{\circ}$ software (MRC-Holland). MLPA ratios less than 0.75 were considered as deletions, those between 0.75 and 1.30 as normal, and those with ratios more than 1.30 as duplications.

\section{Results}

The IGF1R, IGFALS, and IGFBP3 CNVs were studied in 40 short stature children. All our patients have normal karyotype and were screened for SHOX abnormalities and negative for $\mathrm{SHOX}$ CNVs. Our patients comprised 5 males and 35 females. Their age ranged between 2 and 16 years and their height between -2.0 and -6.5 SD. Exactly 19 out of the 40 patients (47.5\%) had a positive family history of short stature (Table 1).

Heterozygous deletion of IGF1R exons 4 through 21 was detected (Fig. 1) in one patient (2.5\%). He was born from a consanguineous marriage, diagnosed with intrauterine growth retardation (IUGR), and had a low birth weight of $1.7 \mathrm{~kg}(-3 \mathrm{SD})$. Upon examination at 4 years, his height was $86.5 \mathrm{~cm}(-3.8 \mathrm{SD})$ of his peers. He had microcephaly, head circumference of $46.0 \mathrm{~cm}(-2.9 \mathrm{SD})$, and a delayed bone age. The GH level and thyroid function tests and his IQ test yielded normal results. His karyotype was normal (Fig. 2). His mother $(145.0 \mathrm{~cm}$; $-2.85 \mathrm{SD})$ and father were short $(159.0 \mathrm{~cm} ;-2.3 \mathrm{SD})$. His family history revealed a short cousin. However, no DNA was available to evaluate the detected CNVs in the family members. 
Table 1 clinical data and growth hormone levels of studied patients

\begin{tabular}{|c|c|c|c|c|c|c|c|}
\hline Patient No. & Sex & Age & Low birth weight & Consanguinity & Family hist. & SDS & GH \\
\hline 1 & $\mathrm{~F}$ & 7 & + & - & + & -2.75 & $\mathrm{~N}$ \\
\hline 2 & $\mathrm{~F}$ & 8 & - & - & - & -3.4 & $\mathrm{~N}$ \\
\hline 3 & $\mathrm{~F}$ & 6 & - & - & - & -2 & $\mathrm{~N}$ \\
\hline 4 & $\mathrm{~F}$ & 6.5 & - & + & - & -3 & $\mathrm{~N}$ \\
\hline 5 & $\mathrm{~F}$ & 13 & - & - & - & -3.1 & N \\
\hline 6 & $\mathrm{~F}$ & 11 & - & + & - & -3.5 & N \\
\hline 7 & $\mathrm{~F}$ & 16 & + & - & + & -2.8 & $\mathrm{~N}$ \\
\hline 8 & $\mathrm{~F}$ & 10 & - & + & - & -3.6 & Mild low \\
\hline 9 & $\mathrm{~F}$ & 13.5 & - & + & - & -6.5 & $N$ \\
\hline 10 & M & 6 & + & + & - & -5.6 & $N$ \\
\hline 11 & $\mathrm{~F}$ & 15.5 & - & - & - & -3 & $N$ \\
\hline 12 & $\mathrm{~F}$ & 12 & - & - & - & -2.5 & $N$ \\
\hline 13 & $\mathrm{~F}$ & 7.75 & - & - & - & -3 & $N$ \\
\hline 14 & M & 3 & - & + & - & -5 & $N$ \\
\hline 15 & $\mathrm{~F}$ & 2 & - & - & - & -2.9 & $N$ \\
\hline 16 & $\mathrm{~F}$ & 11 & - & - & - & -3 & $N$ \\
\hline 17 & M & 12 & - & NA & NA & -3.5 & $N$ \\
\hline 18 & $\mathrm{~F}$ & 16 & - & - & + & -3.5 & Low \\
\hline 19 & $\mathrm{~F}$ & 10 & - & - & - & -2.8 & $N$ \\
\hline 20 & $\mathrm{~F}$ & 16 & - & - & + & -2.9 & Low \\
\hline $21^{*}$ & M & 4 & + & + & + & -3.8 & $N$ \\
\hline 22 & $\mathrm{~F}$ & 8 & - & + & + & -4.6 & $N$ \\
\hline 23 & $\mathrm{~F}$ & 9 & - & - & + & -3.4 & $N$ \\
\hline 24 & $\mathrm{~F}$ & 15.5 & - & + & + & -3.3 & $N$ \\
\hline 25 & $\mathrm{~F}$ & 12 & - & - & - & -3.8 & Low \\
\hline 26 & $\mathrm{~F}$ & 15 & - & - & + & -4.3 & $N$ \\
\hline 27 & $\mathrm{~F}$ & 11 & - & - & + & -4.6 & Mild low \\
\hline 28 & $\mathrm{~F}$ & 9.5 & - & + & + & -2.5 & $N$ \\
\hline 29 & $\mathrm{~F}$ & 12.5 & - & + & - & -3.9 & $N$ \\
\hline 30 & $\mathrm{~F}$ & 12.5 & - & - & - & -3.7 & Low \\
\hline 31 & $\mathrm{~F}$ & 13.5 & - & - & - & -3.3 & $\mathrm{~N}$ \\
\hline 32 & $\mathrm{~F}$ & 9 & - & - & + & -3.9 & Low \\
\hline 33 & $\mathrm{~F}$ & 8 & - & + & + & -4.1 & Low \\
\hline 34 & $\mathrm{~F}$ & 16 & - & + & + & -3.5 & $N$ \\
\hline 35 & $\mathrm{~F}$ & 4.25 & - & - & + & -2.15 & Low \\
\hline 36 & $M$ & 7 & - & + & + & -2.75 & $N$ \\
\hline 37 & $F$ & 11 & - & + & + & -2.5 & $N$ \\
\hline 38 & $\mathrm{~F}$ & 9.5 & - & - & + & -3.3 & Low \\
\hline 39 & $\mathrm{~F}$ & 8.5 & - & - & + & -2.79 & Low \\
\hline 40 & $\mathrm{~F}$ & 6 & - & - & - & -2.5 & $N$ \\
\hline
\end{tabular}




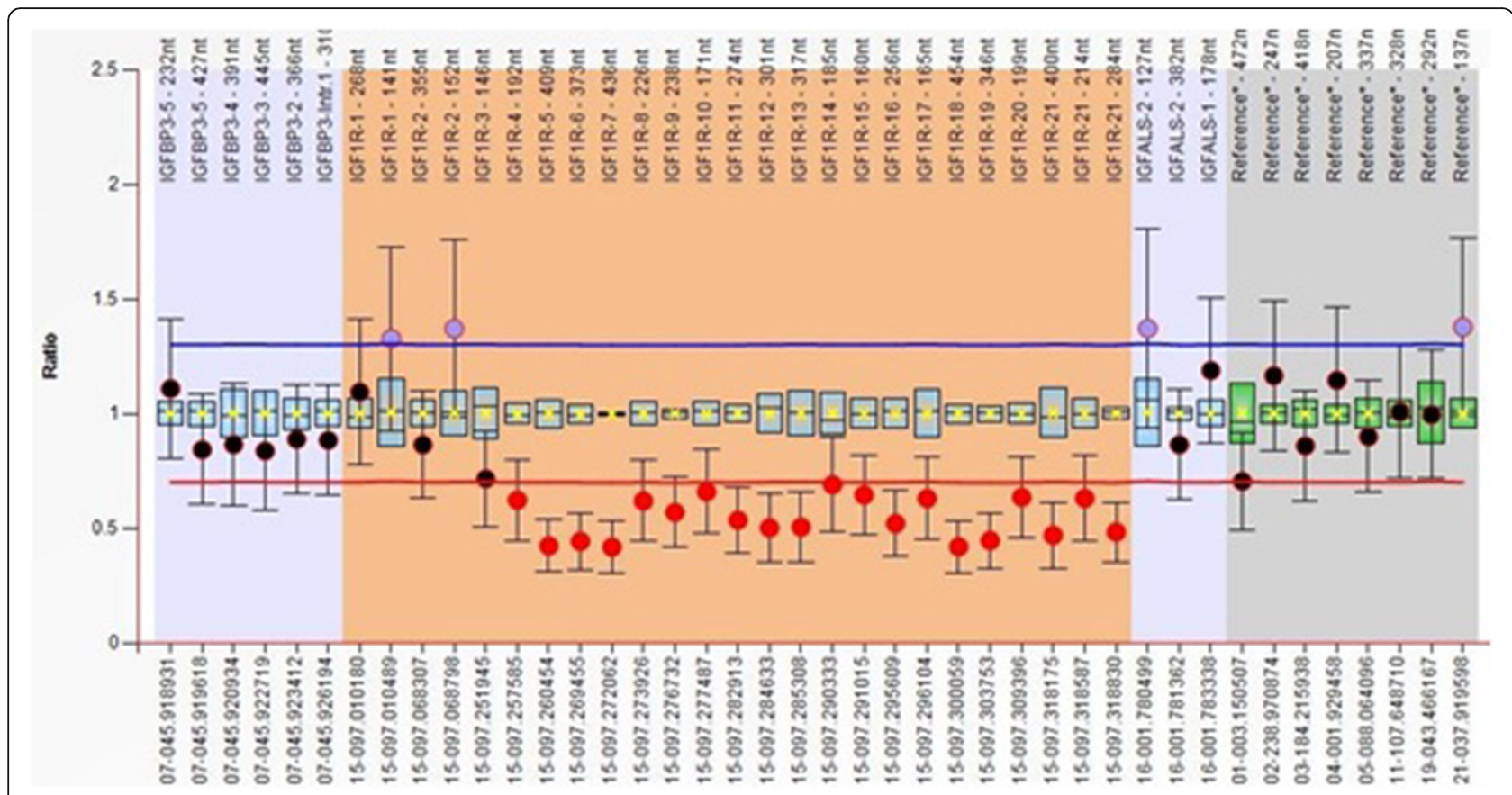

Fig. 1 Ratio chart of MLPA results for a patient with short stature using SALSA MLPA probemix P217-B2 IGF1R. The chart shows the heterozygous deletion of IGFIR (exons 4 through 21). The deletion is denoted by the red spot below the deletion cut-off line (red) in the ratio chart

\section{Discussion}

IGF-I/IGFIR signaling pathway plays an important role in pre- and postnatal growth. The proper genetic diagnosis may result in an appropriate therapy.

IGF1R signaling is reduced in IGF1R haploinsufficiency, although occasionally, the IGF-I response may remain normal. Further assessment of the bi-allelic expression of the IGF1R gene to reach the normal level of activity is needed [11, 31-33].

$I G F 1 R$ haploinsufficiency may be the result of allelic loss of IGF1R due to chromosomal 15q26 deletions [16] or specific allelic IGF1R mutations that abrogate mRNA $[3,11,32]$.

In our work, we detected the heterozygous deletion of IGF1R (exons 4 through 21) in a familial short stature patient identified from the 40 studied patients (2.5\%). This finding was consistent with other group findings who found 2 in 100 SGA patients with IGF1R gene mutations in one study and detected 2 in 128 SGA patients with IGF1R heterozygous deletion in another research $[3,15]$.

Our patient had IUGR and was born SGA. This condition was in line with the clinical criteria that were proposed for heterozygous IGF1R mutations or terminal chromosome 15q deletions, including a small body size and head circumference at birth, short stature, and microcephaly later in childhood [15]. Moreover, a study detected a $50 \%$ reduction in the IGF1R expression on the cell surface by (fluorescence-activated cell sorting) FACS, and this result may explain the SGA phenotype [11].

In our research, we did not detect any patients with IGFALS CNVs. A study reviewed the work conducted on ALS complete deficiency in 61 patients from 31 families from different published reports and discovered that the 28 different mutations of the human IGFALS gene, including 17 missense, 7 frameshift, 2 in-frame insertions, and 1 nonsense mutation, are all located in exon 2. One patient had a deletion of the entire exon 2 [34, 35]. This finding may indicate the rarity of the CNVs of this gene and explain why no CNVs were detected in our study.

Given that IGFBP3 is the major carrier of IGF1, we investigated IGFBP3 CNVs. By reviewing the genetic causes for short stature, no specific diseases were connected to IGFBP gene alterations in humans [36]. IGFBPs have additional biological functions that are potentially independent of their IGF-binding properties, and growing evidence links them to diseases other than short stature [37-40]. Another study aimed to detect variations in the IGF family in 60,706 people from the Exome Aggregation Consortium and revealed that the loss of expression alleles are extremely low in IGF family genes including IGFBPs $[40,41]$. Moreover, we did not find any IGFBP3 CNVs in our study group. 

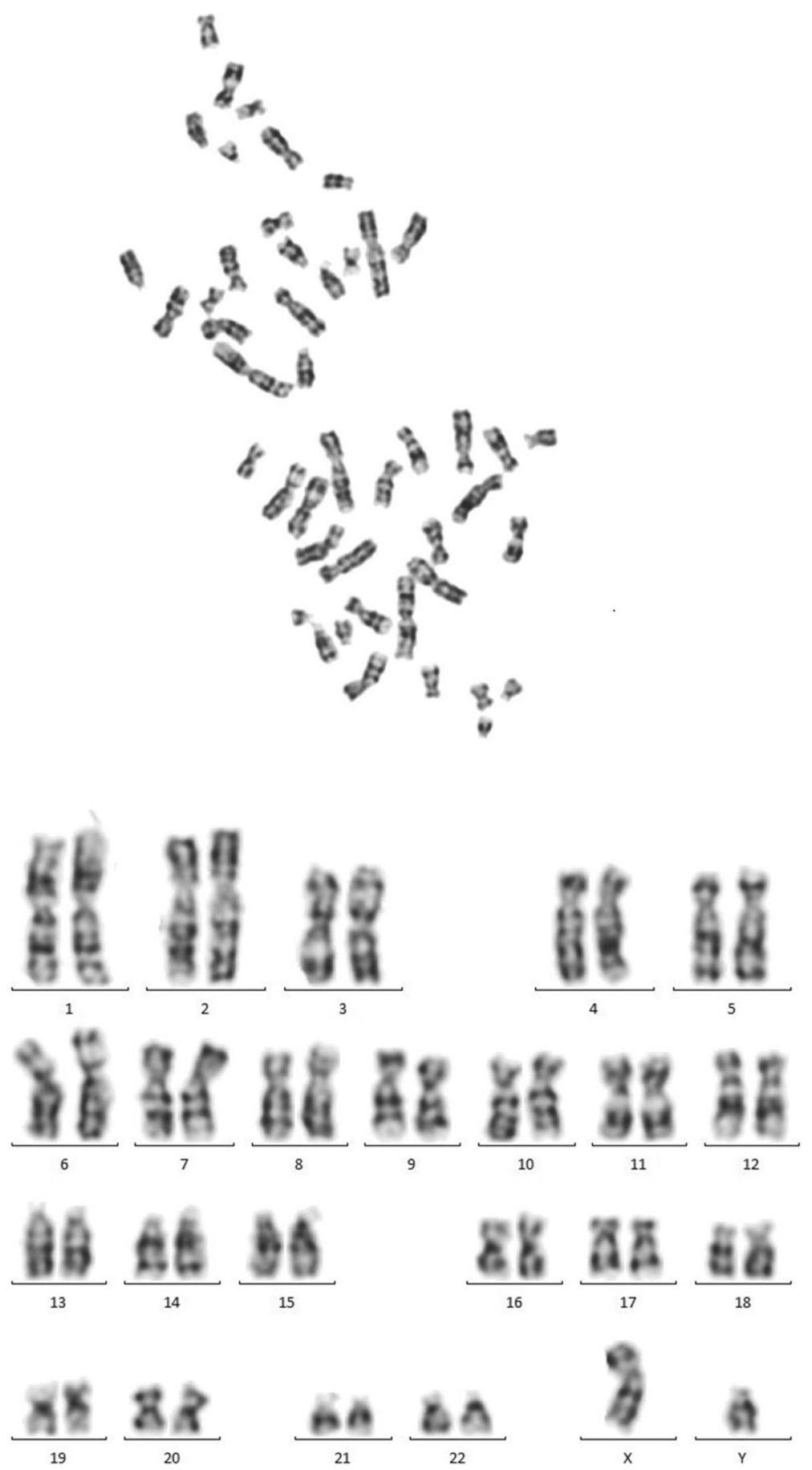

Fig. 2 Metaphase spread and karyotype of our patient showing normal 46,XY karyotype

\section{Conclusion}

In spite of the small sample size, which is considered as a limitation, we identified a familial short stature case having a heterozygous IGF1R partial deletion in a group of Egyptian short non-syndromic patients. In the diagnostic workup of short stature, MLPA can detect the underlying genetic CNVs. Thus, screening with MLPA for CNVs of IGF1R and other recognized genes, such as $S H O X$ and $G H$, that are considered as important regulators of individual height in non-syndromic short stature children can consequently become a fast and inexpensive diagnostic tool to recognize a subcategory of patients in which $\mathrm{GH}$ treatment can be considered. We recommend to carry on MLPA analysis for IGF1R after 


\section{exclusion of chromosomal abnormalities and SHOX CNVs.}

\section{Abbreviations}

ACLS: ALS complete deficiency; ALS: Acid-labile subunit; CNVs: Copy number variants; GH: Growth hormone; IGF1R: Insulin-like growth factor 1 receptor; IGFBPS: IGF-binding proteins; IGF-I: Insulin-like growth factor-1; ISS: Idiopathic short stature; IUGR: Intra uterine growth retardation; MLPA: Multiplex ligation-dependent probe amplification; SGA: Small for gestational age

\section{Acknowledgements}

Not applicable.

\section{Authors' contributions}

IF participated in the lab work and wrote the article and made the final submission. MR participated in the clinical selection of cases and reviewed the article. OE proposed the idea of the research and participated in the lab work and in writing the article. NH participated in the lab work and critically reviewed the article. HE and IM selected the patients and performed the clinical assessment. All authors approved the final version for publication.

\section{Funding}

This work was funded by the National Research Centre.

\section{Availability of data and materials}

Data and materials are available upon request.

\section{Declarations}

\section{Ethics approval and consent to participate}

Ethical approval for this research was granted by National Research Centre Medical Ethical Committee (approval no. 16-274), in accordance with the ethical standards of the Declaration of Helsinki. Informed written consent was obtained from parents of the included cases for history taking, examination, collection of samples, performance of molecular analysis, and scientific publishing of the data.

\section{Consent for publication}

Not applicable.

\section{Competing interests}

The authors have no conflicts of interest to declare.

\section{Author details}

'Department of Human Cytogenetics, National Research Centre, El Buhouth St., Dokki, Cairo 12622, Egypt. ${ }^{2}$ Department of Medical Environmental Research, Institute of Environmental Studies and Research, Ain Shams University, El Khalifa El Maamon Street, Cairo 12622, Egypt. ${ }^{3}$ Department of Clinical Genetics, National Research Centre, El Bohouth Street, Dokki, Cairo 12622, Egypt.

Received: 6 April 2021 Accepted: 27 June 2021

Published online: 28 July 2021

\section{References}

1. Richmond EJ, Rogol AD (2021) In: Snyder PJ, Geffner ME (eds) Causes of short stature, in UpToDate, Waltham Accecssed online: https://www.uptoda te.com/contents/causes-of-short-stature.

2. Renes JS, van Doorn J, Hokken-Koelega ACS (2019) Current insights into the role of the growth hormone-insulin-like growth factor system in short children born small for gestational age. Horm Res Paediatr 92(1):15-27 https://doi.org/10.1159/000502739

3. Caliebe J, Broekman S, Boogaard M, Bosch CAJ, Ruivenkamp CAL, Oostdijk W, Kant SG, Binder G, Ranke MB, Wit JM, Losekoot M (2012) IGF1, IGF1R and SHOX mutation analysis in short children born small for gestational age and short children with normal birth size (idiopathic short stature). Horm Res Paediatr 77(4):250-260 https://doi.org/10.1159/000338341

4. Abuzzahab MJ, Schneider A, Goddard A, Grigorescu F, Lautier C, Keller E, Kiess W, Klammt J, Kratzsch J, Osgood D, Pfäffle R, Raile K, Seidel B, Smith RJ, Chernausek SD (2003) IGF-I receptor mutations resulting in intrauterine and postnatal growth retardation. N Engl J Med 349(23):2211-2222 https://doi. org/10.1056/NEJMoa010107

5. Baker J, Liu JP, Robertson EJ, Efstratiadis A (1993) Role of insulin-like growth factors in embryonic and postnatal growth. Cell. 75(1):73-82. https://doi. org/10.1016/S0092-8674(05)80085-6

6. Adams TE, Epa VC, Garrett TP, Ward CW (2000) Structure and function of the type 1 insulin-like growth factor receptor. Cell Mol Life Sci 57(7):1050-1093 https://doi.org/10.1007/pl00000744

7. Klammt J, Pfäffle R, Werner H, Kiess W (2008) IGF signaling defects as causes of growth failure and IUGR. Trends Endocrinol Metab 19(6):197-205 https:// doi.org/10.1016/j.tem.2008.03.003

8. Suh Y, Atzmon G, Cho MO, Hwang D, Liu B, Leahy DJ, Barzilai N, Cohen P (2008) Functionally significant insulin-like growth factor I receptor mutations in centenarians. Proc Natl Acad Sci U S A 105(9):3438-3442 https://doi.org/1 $0.1073 /$ pnas.0705467105

9. Wallborn T, Wüller S, Klammt Jr, Kruis T, Kratzsch Jr, Schmidt G, Schlicke M Müller E, Schmitz van de Leur H, Kiess W, Pfäffle R (2010) A heterozygous mutation of the insulin-like growth factor-I receptor causes retention of the nascent protein in the endoplasmic reticulum and results in intrauterine and postnatal growth retardation. J Clin Endocrinol Metab 95(5):2316-2324 https://doi.org/10.1210/jc.2009-2404

10. Inagaki K, Tiulpakov A, Rubtsov P, Sverdlova P, Peterkova V, Yakar S, Terekhov S, LeRoith D (2007) A familial insulin-like growth factorreceptor mutant leads to short stature: clinical and biochemical characterization. J Clin Endocrinol Metab 92(4):1542-1548 https://doi. org/10.1210/jc.2006-2354

11. Ocaranza P, Golekoh MC, Andrew SF, Guo MH, Kaplowitz P, Saal H, Rosenfeld RG, Dauber A, Cassorla F, Backeljauw PF, Hwa V (2017) Expanding genetic and functional diagnoses of IGF1R haploinsufficiencies. Horm Res Paediatr 87(6):412-422 https://doi.org/10.1159/000464143

12. Walenkamp MJ, de Muinck Keizer-Schrama SM, de Mos M, Kalf ME, van Duyvenvoorde HA, Boot AM, Kant SG, White SJ, Losekoot M, Den Dunnen JT, Karperien M, Wit JM (2008) Successful long-term growth hormone therapy in a girl with haploinsufficiency of the insulin-like growth factor-I receptor due to a terminal 15q26.2->qter deletion detected by multiplex ligation probe amplification. J Clin Endocrinol Metab 93(6):2421-2425 https://doi.org/10.1210/jc.2007-1789

13. Netchine I, Azzi S, Houang M, Seurin D, Perin L, Ricort JM, Daubas C, Legay C, Mester J, Herich R, Godeau F, Le Bouc Y (2009) Partial primary deficiency of insulin-like growth factor (IGF)-I activity associated with IGF1 mutation demonstrates its critical role in growth and brain development. J Clin Endocrinol Metab 94(10):3913-3921 https://doi.org/10.1210/jc.2009-0452

14. Woods KA, Camacho-Hübner C, Savage MO, Clark AJ (1996) Intrauterine growth retardation and postnatal growth failure associated with deletion of the insulin-like growth factor I gene. N Engl J Med 335(18):1363-1367 https://doi.org/10.1056/nejm199610313351805

15. Ester WA van Duyvenvoorde HA, de Wit CC, Broekman AJ, Ruivenkamp CAL, Govaerts LCP, Wit JM, Hokken-Koelega ACS, Losekoot M (2009) Two short children born small for gestational age with insulin-like growth factor 1 receptor haploinsufficiency illustrate the heterogeneity of its phenotype. J Clin Endocrinol Metab 94(12):4717-4727 https://doi.org/10.1210/jc.2008-1 502

16. Roback EW, Barakat AJ, Dev VG, Mbikay M, Chrétien M, Butler MG (1991) An infant with deletion of the distal long arm of chromosome 15 (q26.1----qter) and loss of insulin-like growth factor 1 receptor gene. Am J Med Genet 38(1):74-79 https://doi.org/10.1002/ajmg.1320380117

17. Rudaks LI, Nicholl JK, Bratkovic D, Barnett CP (2011) Short stature due to 15 q26 microdeletion involving IGF1R: Report of an additional case and review of the literature. Am J Med Genet Part A 155(12):3139-3143 https:// doi.org/10.1002/ajmg.a.34310

18. Boisclair YR, Rhoads RP, Ueki I, Wang J, Ooi GT (2001) The acid-labile subunit (ALS) of the $150 \mathrm{kDa}$ IGF-binding protein complex: an important but forgotten component of the circulating IGF system. J Endocrinol 170(1):6370 https://doi.org/10.1677/joe.0.1700063

19. Guler HP, Zapf J, Schmid C, Froesch ER (1989) Insulin-like growth factors I and II in healthy man. Estimations of half-lives and production rates. Acta Endocrinol (Copenh.) 121(6):753-758 https://doi.org/10.1530/acta.0.1210753

20. Poyrazoğlu S, Hwa V, Baş F, Dauber A, Rosenfeld A, Darendeliler F (2019) A novel homozygous mutation of the acid-labile subunit (IGFALS) gene in a male adolescent. J Clin Res Pediatr Endocrinol 11(4):432-438 https://doi. org/10.4274/jcrpe.galenos.2019.2018.0301 
21. Storr HL, Prasad R, Temple IK, Metherell LA, Savage MO, Walker JM (2015) Heterogeneity of the growth phenotype and birth size in acid-labile subunit (ALS) deficiency. J Endocrinol Invest 38(4):407-412 https://doi.org/10.1007/s4 0618-014-0195-1

22. Rosenfeld RG, Hwa V (2009) The growth hormone cascade and its role in mammalian growth. Horm Res Paediatr 71(suppl 2):36-40 https://doi.org/1 $0.1159 / 000192434$

23. Walenkamp MJE, Wit JM (2006) Genetic disorders in the growth hormone insulin-like growth factor-I axis. Horm Res Paediatr 66(5):221-230 https://doi. org/10.1159/000095161

24. Walenkamp MJE, Wit JM (2007) Genetic disorders in the GH-IGF-I axis in mouse and man. Eur J Endocrinol 157(suppl_1):S15 https://doi.org/10.1530/ eje-07-0148

25. Walenkamp MJ, Wit JM (2008) Single gene mutations causing SGA. Best Pract Res Clin Endocrinol Metab 22(3):433-446 https://doi.org/10.1016/j. beem.2008.02.001

26. Im M, Kim Y-D, Han H-S (2017) Effect of growth hormone treatment on children with idiopathic short stature and idiopathic growth hormone deficiency. Ann Pediatr Endocrinol Metab. 22(2):119-124 https://doi.org/10. 6065/apem.2017.22.2.119

27. Veenma DC, Eussen HJ, Govaerts LC, de Kort SW, Odink RJ, Wouters CH, Hokken-Koelega AC, de Klein A (2010) Phenotype-genotype correlation in a familial IGF1R microdeletion case. J Med Genet 47(7):492-498 https://doi. org/10.1136/jmg.2009.070730

28. Eid OM, Eid MM, Abdelrahman AH, Abdel kader RMA, Farid M, Mahrous R, Mekkawy MK, Kamel AK, Mazen I, El-Bassyouni HT (2020). Screening of the SHOX/PAR1 region using MLPA and miRNA expression profiling in a group of Egyptian children with non-syndromic short stature. Egypt J Med Hum Genet 21(1):47. https://doi.org/10.1186/s43042-020-00090-4.

29. Schouten J, McElgunn C, Waaijer R, Zwijnenburg D, Diepvens F, Pals G (2002) Relative quantification of 40 nucleic acid sequences by multiplex ligation-dependent probe amplification. Nucleic Acids Res 30(12):e57. https://doi.org/10.1093/nar/gnf056

30. Eijk-Van Os PG, Schouten JP (2011) Multiplex Ligation-dependent Probe Amplification (MLPA ${ }^{\oplus}$ ) for the detection of copy number variation in genomic sequences. Methods Mol Biol 688:97-126 https://doi.org/10.1007/ 978-1-60761-947-5_8

31. Choi JH, Kang M, Kim GH, Hong M, Jin HY, Lee BH, Park JY, Lee SM, Seo EJ, Yoo HW (2011) Clinical and functional characteristics of a novel heterozygous mutation of the IGF1R gene and IGF1R haploinsufficiency due to terminal 15q26.2->qter deletion in patients with intrauterine growth retardation and postnatal catch-up growth failure. J Clin Endocrinol Metab 96(1):E130-E134 https://doi.org/10.1210/jc.2010-1789

32. Fang P, Schwartz ID, Johnson BD, Derr MA, Roberts CT Jr, Hwa V, Rosenfeld RG (2009) Familial short stature caused by haploinsufficiency of the insulinlike growth factor I receptor due to nonsense-mediated messenger ribonucleic acid decay. J Clin Endocrinol Metab 94(5):1740-1747 https://doi. org/10.1210/jc.2008-1903

33. Hammer E, Kutsche K, Haag F, Ullrich K, Sudbrak R, Willig RP, Braulke T, Kubler B (2004) Mono-allelic expression of the IGF-I receptor does not affect IGF responses in human fibroblasts. Eur J Endocrinol. 151(4):521-529 https:// doi.org/10.1530/eje.0.1510521

34. Dominguez-Menéndez G, Poggi Mayorga $H$, Arancibia M, Benavides F, Martinez-Aguayo A (2019) ALS deficiency caused by an exon 2 deletion and a novel missense variant in the gene encoding ALS. Growth Horm IGF Res 48-49:5-8 https://doi.org/10.1016/j.ghir.2019.07.002

35. Domené S, Domené HM (2020) The role of acid-labile subunit (ALS) in the modulation of GH-IGF-I action. Mol Cell Endocrinol 518:111006 https://doi. org/10.1016/j.mce.2020.111006

36. Dauber A, Rosenfeld RG, Hirschhorn JN (2014) Genetic evaluation of short stature. J Clin Endocrinol Metab 99(9):3080-3092 https://doi.org/10.1210/jc.2 014-1506

37. Bach LA (2015) Insulin-like growth factor binding proteins 4-6. Best Pract Res Clin Endocrinol Metab 29(5):713-722. https://doi.org/10.1016/j.beem.201 5.06 .002

38. Baxter RC (2014) IGF binding proteins in cancer: mechanistic and clinical insights. Nat Rev Cancer 14(5):329-341 https://doi.org/10.1038/nrc3720

39. Ranke MB (2015) Insulin-like growth factor binding-protein-3 (IGFBP-3). Best Pract Res Clin Endocrinol Metab 29(5):701-711 https://doi.org/10.1016/j. beem.2015.06.003
40. Rotwein P (2017) Large-scale analysis of variation in the insulin-like growth factor family in humans reveals rare disease links and common polymorphisms. J Biol Chem 292(22):9252-9261 https://doi.org/10.1074/jbc. M117.783639

41. Bahcall OG (2016) ExAC boosts clinical variant interpretation in rare diseases. Nat Rev Genet. 17(10):584-584 https://doi.org/10.1038/nrg.2016.121

\section{Publisher's Note}

Springer Nature remains neutral with regard to jurisdictional claims in published maps and institutional affiliations.

\section{Submit your manuscript to a SpringerOpen ${ }^{\circ}$ journal and benefit from:}

- Convenient online submission

- Rigorous peer review

- Open access: articles freely available online

- High visibility within the field

- Retaining the copyright to your article

Submit your next manuscript at $\boldsymbol{\nabla}$ springeropen.com 